\title{
Private Islamic Primary School Teachers' Commitment in Human Capital Development in Malaysia
}

\author{
Asmawati Suhid \\ Faculty of Educational Studies, Universiti Putra Malaysia \\ asmawati@upm.edu.my \\ Fathiyah Mohd. Fakhruddin \\ Samsilah Roslan \\ Faculty of Educational Studies, Universiti Putra Malaysia \\ Lukman Abdul Mutalib \\ Faculty of Syariah and Law, Universiti Sains Islam Malaysia \\ Mohd Aderi Che Noh \\ Faculty of Education, Universiti Kebangsaan Malaysia
}

\section{Doi:10.5901/mjss.2014.v5n27p766}

\section{Abstract}

\begin{abstract}
In general, education is a continuous process to educate and develop individuals to a more meaningful life in this world and in the hereafter. In order to educate, the role of education is to nuture and develop human interests, the importance of which had been acknowledged by most societies. Thus various measures and efforts have been made to strengthen the educational process to be followed by each generation level. Currently, PIPS is an alternative education for parents in Malaysia other than the National Schools under the Ministry of Education. The mushrooming of the Private Islamic Primary Schools has been seen as a result of the high demand from the society. The society, particularly the parents have put high expectations in the education in these schools which emphasized not only the religious subjects but also the academic ones to produce a balanced and integrated human capital. Thus, this study was carried out to explore the PIPS teachers' commitment in fulfilling the responsibilities and trusts undertaken to realise the noble needs.
\end{abstract}

Keywords: Teachers' commitment, Private Islamic Primary School, Human Capital

\section{Introduction}

Teachers play an important role in ensuring the effectiveness of the teaching and learning process towards the success of the schools. This is because not only teachers are mu'allim but also as murabbi and muaddib who emphasize the holistic development of the pupils in terms of the intellect, spiritual, physical and moral.

The success of the pupils too should not be viewed from the academic point of view only but also from their personality and spirituality. Hence, the ultimate success and excellence of a school if viewed from the Islamic perspectives include the development and practices based on Islamic values.

The emergence of the Private Islamic Primary Schools (PIPS) in Malaysia gives hope to parents and the community for their children to receive a holistic education. This is evident by the many PIPS establishments caused by the rising demands from parents. Thus, the PIPS teachers should be responsible and the trust to be given sincerely and earnestly so that the the generation and human capital are produced truly according to the Islamic mould. The teachers' commitment is crucial in ensuring the pupils' and schools' success becoming a realisation. 


\section{Literature Review}

This section will discuss about the concept of education in Islam, the establishment of Private Islamic Primary Schools (PIPS) and the commitment of teachers in their job.

\subsection{The concept of education in Islam}

The human capital development is closely related to the Islamic Education. The word 'education' itself originated from the Arabic word ربى, which means 'fertile', 'increase' and 'improve'. Thus tarbiyyah or education is a human behaviour in caring, nurturing, and educating a person until he becomes better than before.

According to Profesor Said Ismail Ali, Islamic education is defined as an integrated system, sourced from the alQuran, the sunnah of the Prophet (pbuh), experiences and experts' opinions with the aim of building the ideal human character who is able to create progress, instill servitude and assume responsibility of khalifatullah fi al-Ard (Said Ismail Ali 2007:16). Based on his definition, there are several key elements that form the Islamic education, i.e. firstly it is an integrated system. Integrated between the worldly and hereafter, between the physical, spiritual and emotional and between theory and practice. Secondly, Islamic education was sourced from the revelation and ijtihad (reasons). Revelations make it rigid in nature while ijtihad has an element of flexibility that may posssibly make it relevant and able to take on any current challenges. Thirdly, the aims or objectives are to build the ideal human personality. This personality is reflected through three main characteristics, i.e. creative and innovative minds in driving progress, character and a strong sense towards Allah SWT and mankind who govern them from greediness and selfishness and finally having leadership distinction appropriate to the concept of khalifatullah fi al-Ard in self, family, society and country.

Without doubt Islamic education leads to the formation of the human capital based on sublime faith. Among the unique features of Islamic education is building a strong relationship between man and Allah SWT. Actually this relationship will govern all human behaviour in their daily life. Whether alone or with friends, they will always be cautious so as not to get caught in things forbidden by Allah SWT. Basically, Islamic education instills fear of Allah SWT and of His wrath in the afterlife.

In general the aim of Islamic education is to build an admirable human personality as illustrated in the above concept of Islamic education. But in detail, it can be divided into two i.e. the goals in the individual context and the goals in the societal context (2007:101).

Individually, Allah revealed that every human being is responsible for what he did. Allah commanded which means, "and he will come to Us alone " (Chapter Maryam 19:80), "and each of them will come on the Day of Judgment alone" (Chapter Maryam 19:95), "indeed, you will definitely come to Us (on the Day of Judgment) alone as when We first created you" (Chapter al-An'am 6:94). The above verses clearly showed the individual human responsibility to Allah SWT. Among the aims of Islamic education in the indidual context are:

\subsubsection{Worship to Allah SWT}

This is the main aim. Allah commanded which means, "We did not create jinn and mankind other than they worship Us" (chapter al- Zariyaat 51:56). Worshipping Allah SWT will shape the rabbani characteristic as they have established a close relationship with Allah SWT. Allah warned which means, "Be ye faithful Rabbaniyin (who only worship Allah - with complete knowledge and deeds), because you are always teaching the content of the Book of Allah, and because you have always studied (Chapter Ali Imran 3;79).

The worship to Allah SWT is not merely done to form correct understanding and confidence in Allah SWT but also to educate the noble characteristics, hygiene, health, self beauty and so on (Khalid Muhammad 2006:58). For example praying practices. Besides instilling the characteristics of humility and servitude to Allah SWT, it is also to remind us the importance of time, discipline, cleanliness, self purity, place and clothing, health, innate and physical beauty, to work together, cooperate, compromise, to live in a society and others.

\subsubsection{Adorn oneself with good character}

In this context the Prophet (pbuh) stated which means, "indeed, I am sent to perfect the noble character" (Narrated by Baihaqy). To perfect the character was the main message of the prophethood of Prophet Muhammad (pbuh). Character is the nature that self decorates the mankind, it is the spontaneous reactions that occur as a result of the intrinsic nature of the man himself. It develops gradually until it sticks strongly in the heart. Character is divided into three categories. 
First, good character for Allah SWT, second, for mankind and third for the environment. By implementing all the prophet's (pbuh) teachings, man will possess noble character and will be very productive.

\subsubsection{Taking care of one's health}

Taking care of one's health is given great importance in the Islamic teachings. This is because all forms of worship to Allah SWT require good health. Haj pilgrimage for instance would be impossible unless they have satisfactory health. Similarly, other religious duties such as fasting and praying would not be complete without adequate good health. The sensitivity of the Islamic teachings towards health issues is touched upon in many places. Among the issues are on food. Allah SWT commanded that we eat food that are 'halalan tayyiba' 'Halal' which means food that can be eaten. Eating foods that are 'haram' (forbidden) not only would jeopardise health but also would lead to bad character. While tayyiba means quality food (Halal haram 2006:14-15). Allah commanded which means, "O mankind! Eat from what are on earth which are halal and good, and do not follow the Satan's foodsteps; because indeed, the Satan is your clear enemy (Chapter al-Baqarah 2: 168). The call for health care can also be seen from Allah's prohibition against certain things like drinking alcohol, eating carrions, adultery and others. It is clear, body health influences one's mind and soul to be productive and proactive. In this context, the Prophet (pbuh) stated which means, "the strong believers are better and loved by Allah SWT than those believers who are weak" (Narrated by Bukhary and Muslim).

The Prophet (pbuh) also made comparisons between the strong believers and the weak ones to the date tree standing strongly and the dry and old date tree that would fall even when someone just leaned onto it.

\subsubsection{To increase self competency and competitive ability}

Islam is a great and noble religion. Thus, the aim of Islamic education is not just being able to do something, but being able to do the best ((Said Ismail 2007: 123). Verses of the al-Quran not only brought hidayah (guidance) to mankind, but it posseses good grammar and high literary works. This shows a person needs to do something above his ordinary capability. This is what is meant by competitive ability. When Allah SWT demanded mankind to look at camels, clouds, mountains, seas and so on, it does not mean by normal visions but by fully observable visions. In the al-Quran, Allah SWT commanded, which means,"truly the best person for thee to employ is the one who is strong, and trustworthy" (Chapter al-qasas 28: 26). Strong in the modern definition is competence while trust is integrity. Competency is a very necessary attribute to a Muslim no matter what field of endeavor. If he is a teacher, then be a competitive teacher, if a taxi driver, then be a competitive one. In this issue the prophet (pbuh) stated, which means, "Indeed Allah loves a person when he does things, he does it with deligence and care" (narrated by al-Baihaqy $1410 \mathrm{H}$ )

The aim of Islamic education in the context of Society are:

\subsubsection{Building wisdom through life experiences}

Experience is a practice or human behaviour driven by a cause to achieve a purpose or a specific goal (Said Ismail Ali 2007: 127). Starting from the point of cause to the point of specific goal, there would be several activities which are, thinking and physical activities. Thus experiences are the combination of these two well- established activities. A student often utilises his brain in the process of understanding the learning content. However, to further facilitate the comprehesion, he needs to practise the learning process correctly and appropriately. Both of these processes are referred to as learning through experiences. Allah SWT reprimanded those who do not observe life ecxperiences. Allah commanded, which means, "they have hearts but do not try to understand, they have eyes but do not try to look, they have ears but do not try to hear. They are like farm animals, even more misguided than that..." (Chapter al-A'raaf: 179). What is explained in this verse, those who separate or break the relationship between mental activities and life experiences, they are like farm animals and worse than that because animals are not given the ability to think like humans. In the al-Quran Allah SWT commanded, which means, "because they do not walk on this earth and see what happened to the those before them, while those before them were more strong and powerful than them? (Chapter alRum: 9). While the Prophet (pbuh) stated, which means, "a believer should not be bitten by a snake from a hole twice" Narrated by Bukhary \& Muslim (Humaidy 2002 vol. 3:13)

\subsubsection{To activate the world and manage the Muslim community}

Islam considers mankind as the most valuable capital in building a civilised nation. To invest properties to build high 
attitude in mankind is the best investment and a guarantee in the continuity of investments in fields such as agriculture, industry, business and so on. Hence, Islam places great importance in the building of high attitude. The Prophet (pbuh) stated, which means, "this world is a decoration, the best decorations are women who are salihah (pure)" narrated by Muslim (Muslim Jil 4: 178). The Hadith explained the importance of human capital which is described as solihah women because they are the earliest and the most important educators in building generations of quality. Islam encourages innovations, and creativity, hence Allah SWT provided humankind with the said capability of the thinking mind. Allah SWT commanded, which means "Do they willingly not use their effort to ponder the content of the Al-Quran? Or are their hearts locked up (prohibiting from receiving the teachings of Al-Quran)? (Chapter 47: 24). In many verses related to the enviroment, Allah SWT urged mankind to take this mental advantage. For example, Allah SWT commanded, which means, ".do they not wish to see how camels were created, and how the sky was exalted, and how mountains were uprighted and the earth was spread out? (Chapter al-Ghasyiah 88: 17-20). In the context of managing the community, we have been shown well and clear by history from the Prophet (pbuh), and his companions. Too much had been done by the Prophet's (pbuh) companions, especially Sayidina Umar al-Khattab in innovating the govermental sysytem in creating a wide range of reforms especially in management. These examples could be directly referred to in the more specific books.

If we look at all the aims of the Islamic education, it actually narrows down to the development of high human capital. Quality human capital would develop Malaysia especially in achieving the aims of the developed nation status within the planned time frame.

\subsection{The establishment of PIPS in Malaysia}

PIPS refers to schools that are established on the inniatives of organisations or a group of particular individuals. It certainlay did not include schools fully built by the Federal Government or financially aided schools or state-run schools. In general private schools in Malaysia encompass Islamic and non-Islamic schools such as pondok schools, tahfiz schools, Islamic primaray schools, Islamic secondary schools, correspondence schools, international schools and schools for the expatriates.

Based on the records issued by the Private Education Division, Malaysian Ministry of Education, until June 30, 2012 there are 32 registerd PIPS. This figure seems small compared to the gross investigation on the numerous PIPS especially established in big cities. This reality is due to, there are private Islamic schools that are not registered with the Private Education Division besides others that are registered with The State Islamic Religious Department (Fathiyah, Asmawati, Lukman dan Samsilah, 2013).

If we traced the history of the early establishments of PIPS in Malaysia, it was triggered by the innitiatives of several organisations or the Islamic movements. Such Islamic movements like the Parti Islam SeMalaysia (PAS), Angkatan Belia Islam Malaysia (ABIM) and the Jemaah Islah Malaysia (JIM) took steps to open the Islamic primary and secondary schools and the tertiary levels to make changes to the existing national education system (Badlihisham Mohd Nasir, 2010). For example, PAS established the Islamic primary school known as Sekolah Rendah al-Munir in Terengganu and Sekolah Rendah Islam Darul Ulum (SRIDU) in Kedah in the 1990s. While following that, the Islamic movement ABIM also took similar steps to establish Islamic schools known as Islamic Primmary School (IPS). Further, the organisation of Jemaah Islah Malaysia, as a social missionary movement, emphasised on education to implement the renewals or reformations or islah. JIM was not left behind in establishing the Islamic primary schools known as Sekolah al-Amin. Sekolah al-Amin has a network of schools in most states in Malaysia and received favourable response from the local communities (Badlihisham Mohd Nasir, 2010). It should be stressed here, that all three Islamic movements were not only successful in establishing the Islamic primary schools that received a lot of community attention, but also in establishing the network of early childhood education (kindergartens), primary, secondary and tertiary education.

The establishment of PIPS was driven by several factors that could be understood. First, the community felt that the social turmoils in the society, especially among the young ones were caused by the breakdown in the education sysem that did not emphasise on the integration between academics and religion. Education based on religion and the existing universal Islamic values are believed to be able to address the social problems that befall today's society. Second, the community realised that the existing education system had shown many clearly seen evidences that it could only produce intellectuals but are barren in character and religious values. This caused irregularies and various crimes that still occur even among the intellectuals. Third, PIPS was established as a result of the needs and demands for a holistic education with Islam as its core and taking into account the acquisition of the English language and information technology skills (Rosnani Hashim, 2007). Thus, several PIPS that supported holistic Islamic education utilise the English language as a medium of instruction and information technology is optimally utilised in the teaching and learning process. 
It may be summarised that the establishment of the PIPS in Malaysia was an important implication from the community's awareness towards the importance of a holistic and integrated education system. The establishment of the said schools made a great contribution to the national education. It is a form of choice and also a platform for parents to assist the governmentin bearing the community's demands for the limited public Islamic schools. Nevertheless, the presence of the PIPS also has challenges and contraints that need efforts for improvements. These efforts narrow down towards improving the schools' infrastructures, teacher training, and the schools' financial, administrative and management problems.

\subsection{PIPS teachers' commitment in human capital development}

The term commitment is commonly used to refer to the characteristics or attributes that are very important in every employee, especially teachers. It refers to the characteristics of caring and dedication and more importantly responsibility and duties over self interests (Nias, 1989). Commitment is considered as a compulsory universal charateristic in all teachers. Studies on teacher commitment started as early as the 1950s (Tsui \& Cheng, 1999). Most of these studies focused on identifying the components of commitment in the early stages of commitment ccntering more on the extent of teachers' work achievement in the schools' organisation. Elements of teacher commitment then was explored as more multidimensional involving not just the commitment to schools, but also commitment to the students as well as knowledge and professional skills (Tyree, 1996). These studies also found that commitment was closely related to teachers' values and ideology (Sun, 2004). Teachers who were commited would constantly adapt themselves to various reforms and changes in education and able to achieve career satisfaction (Elliott \& Crosswell, 2001).

The importance of teacher commitment in supporting the achievement of the targets in education is irrefutable. Teacher commitment is the most critical factor in ensuring the quality of teaching, schools' organisational achievements, students' attitude and achievement and more so the learning outcomes and the set aims. Hence, teacher commitment is the fundamental element in determining the success and the future of education (Watson \& Hutton, 2002).

Among the various demographic elements that had been associated with teacher commitment, the most important were length of service and experiences (Huberman, 1993). However, from the various studies in the world, the patterns were found to be inconclusive where there were studies that reported increased commitment was consistent with the length of working experience, and other findings that found otherwise. This was possibly be due to factors such as fatigue or burnout, especially if the given work load was beyond than what it should be.

Among the interesting aspect to explore associated with commitment is place of work. In Malaysia, there are two types of school i.e. the government schools and the private schools. Among the distinct differences of these two types of school are in terms of work load, job benefits, stability and equality in emolument and allowance. The commitment level and patterns reflected by the PIPS teachers could provide insight on the extent to which the context of the work place and social environment influence the level of commitment that teachers are willing to contribute. Hence this study was conducted to explore PIPS teachers' commitment in fulfilling the responsibility and trust undertaken to realise these noble intentions.

\section{Purpose of Study}

In general the aim of this study is to identify the level of PIPS teachers' commitment in performing their duties and resposibilities in developing and educating the pupils.

\section{Methodology}

The research methodology includes the research design utilised, population and sampling, research instruments and types of data analysis. It can help provide an insight into the strength of the findings presented by a study.

\subsection{Reseach design}

The research design is the fundamental structure of a study. It is a form of systematic strategies in conducting a research. Through research designs, a reseacher can obtain answers to questions more objectively, accurately and more reliable and economical (Kerlinger, 1986). This study utilisesd the quantitative approach based on the survey desc riptive design. This design is deemed suitable to providr a comprehensive insight on the variables under study i.e. PIPS teachers' commitment in human development in Malaysia. 


\subsection{Population and sampling}

The target population of this study were the PIPS teachers in Malaysia. However, the reasonable sample size determination was based on the analysis of the power of the sample size. This was because the statistical power could guide the researcher on the extent that his study could be economically continued by obtaining similar findings if the same study is to be repeated in the future by other researchers (Othman Mohamed, 2001). Therefore based on Borg and Gall (1983), the smallest sample size for correlational analysis is 30. Again according to the resolution made by Fraenkel and Wallen (1996), descriptive studies must have a minimum of 100 subjects. While for correlational studies, the number is fixed at 50 . In Social Science studies, it is sufficient to have the sample size with the power of .8, with medium effect size of .30 and the significant level at $\alpha=.05$.

For this study, the sample size determination was done by referring to the Table by Krejcie \& Morgan (1970). The Stratified Random Sampling was utilised to obtain the sample of teachers. A total of 305 questionnaires were recieved but only 284 were fully completed and analysed.

\subsection{Location of study}

In this study, the study locations represented all the PIPS in Malaysia according to the predetermined zones i.e. north zone, central zone, east zone and the south zone.

\subsection{Research instrument}

A set of questionnaires was used to obtain data and information from the PIPS teachers. The research instrument was developed by taking into consideration sugesstions from Cohen, Manion \& Morrison (2001) and a panel of experts who verified the validity and the reliability of the instrument. The Cronbach Coefficient Alpha (DeVellis, 1995) method was applied to obtain the reliability index of the developed instrument.

\subsection{Data analysis}

To analyse the data related to the implementation of the PIPS, descriptive statistics that involved percentages, mean and standard deviations were utilsed for the pattern and level of commitment of the PIPS teachers' in human development. Qualitative data obtained were analysed using the Statistical Package For The Social Sciences (SPSS).

\section{Findings and Discussion}

\subsection{Respondents' Demography}

Table 1: PIPS Teachers' Demography

\begin{tabular}{|l|l|c|c|}
\hline & & f & \% \\
\hline \multirow{2}{*}{ Gender } & Male & 54 & 19.0 \\
& Female & 230 & 80.9 \\
\hline \multirow{2}{*}{ Teaching Certificate } & Ya & 29 & 10.2 \\
& Tidak & 255 & 89.8 \\
\hline \multirow{3}{*}{ Highest Academic Level } & SPM & 30 & 10.7 \\
& STPM & 39 & 14.0 \\
& Diploma & 77 & 27.5 \\
& Bachelor & 116 & 41.4 \\
& Master & 4 & 1.4 \\
& Others & 14 & 5.0 \\
\hline
\end{tabular}

Based on Table 1 above, the respondents consisted of 230 female teachers and 54 male teachers. In terms of the highest academic level, the majority of the teachers surveyed were bachelor degree holders (41.4\%) and followed by diploma holders (27.5\%). The majority or most of the teachers surveyed did not have teaching certficates (89.8\%). However, to overcome this deficiency, the researchers found that the teachers had attended several trainings or courses such as those related to teaching and learning methods (71.2\%), planning of teaching preparations (77.9\%), classroom 
control and management (66.7\%), and teaching aids (58.6\%). However, the findings showed that more than fifty percent of the teachers did not or had not attended courses related to computer literacy. Exposure to the attractive use of computers and softwares is essential in teaching and learning to diversify the teaching aids utilised. Not only that, teachers should also be exposed to the use of sophisticated and comprehensive multi-media technology in accordance with the the current advancement of technology. The findings also showed that only $42.3 \%$ of the teachers had attended thinking skill courses. It is important to instill thinking skills among pupils in order to produce critical, creative and innovative individuals. As according to Ahmad Mohd. Salleh (2004), to achieve Vision 2020, education in Malaysia must make thinking skills as the basis in knowledge acquisition and skills in all subjects.

\subsection{PIPS teachers commitment in human capital development}

Based on Table 2 below, it was found that PIPS teachers had a high level of commitment. This was because all the mean values obtained were between 4.00-5.00. Teachers were found to have very high commitment, for example they "strive to improve their performance in schools from time to time" (mean=4.44, SD=.652), "strive to do the best for the school" (mean=4.41, SD=.660), and "strive to improve the quality of the school" (mean=4.35, SD=.668). The majority of the teachers (mean=4.37, SD=.603) also felt responsible towards their work.

Table 2 : PIPS Teachers Commitment

\begin{tabular}{|c|l|c|c|}
\hline No & Item/Statement & Mean & SD \\
\hline 1 & Happy to spend my whole career as a teacher in this school. & 4.19 & .797 \\
\hline 2 & Accept the problems of the school as my problems. & 3.92 & .881 \\
\hline 3 & Sense of belonging to the school. & 4.25 & .755 \\
\hline 4 & Feeling comfortable working in this school. & 4.19 & .761 \\
\hline 5 & Strive to do the best for the school. & 4.41 & .660 \\
\hline 6 & Strive to improve my performance in the school from time to time. & 4.44 & .652 \\
\hline 7 & Strive to improve the quality of the school. & 4.35 & .668 \\
\hline 8 & Commited towards work in the school. & 4.34 & .677 \\
\hline 9 & Satisfied with the service I provide in the school. & 3.95 & .757 \\
\hline 10 & Responsible towards my work. & 4.37 & .603 \\
\hline 11 & Dedicated towards my work. & 4.34 & .646 \\
\hline 12 & Wish to find another job. & 2.93 & 1.428 \\
\hline
\end{tabular}

The researchers were impressed when the majority of the teachers (mean=2.93, $S D=1.428$ ) surveyed denied they wished to find another job. This was due to the feelings of love or sense of belonging towards the school which was rooted in their hearts. Such feelings were important for they created positive attitudes towards the school, pupils and towards themselves. For example, teachers had a sense of responsibilty to improve the quality of the school (min=4.35, $\mathrm{SP}=.668)$ and personal performance ( $\mathrm{min}=4.44, \mathrm{SP}=.652)$. They too would always internalise the values of dedication and commitment towards their assigned duties. Further, the teachers (min=3.92, $\mathrm{SP}=.881$ ) acknowledged that the school's problems were also theirs.

Indeed the duties and responsibilities of a teacher or educator when done with sincerity not only reap rewards on earth but also in the hereafter. Teachers should internalise and instill in their hearts and souls that their duties are a form of trust that should be implemented honestly and with sincerity. In fact in Islam, teachers as murabbi, muaddib and mu'allim assumed an honourable responsibilty. Therefore, teachers should not ignore this honour awarded by Allah SWT by defiling it, just to pursuit worldly rewards. Allah commanded, which means:

Say it, is it the same for those who know with those who do not. Indeed, those who received warning and guidance are only among His learned and wise servants (Al-Quran, chapter az-Zumar: 9)

Allah SWT will raise to several positions among you who are believers and those who are given knowledge.

(Al-Quran, chapter al-Mujadalah:11)

In terms of school comfort, the study showed that teachers (min=4.19, SP=.761) were satisfied and felt comfortable in schools. However, based on the researchers' observations, the infrastrucures in several schools needed to be upgraded such as the library, prayer rooms, assembly halls and toilets. Similarly, sophisticated equipments and teaching aids should be addressed to ensure that pupils experience condusive learning environment, comfortable and 
harmonious learning sessions.

\section{Conclusion}

Based on the study's findings and discussions, it clearly showed that most teachers at PIPS had high commitment to their schools, duties and reponsibilities. As a result of this high commitment PIPS were able to show improvement in the performance of the pupils and schools. Parents too, would not miss this opportunity to send their children to study at PIPS. Therefore, the improvement and progress of PIPS need both the material and non- material support from various parties collectively and effectively. It should also be ensured that PIPS implementation of the schooling system and Teaching \& Learning are based consistently on Islamic law and steadfastness so as to produce individuals who possess the Islamic values and character as servants and messengers of Allah SWT.

\section{References}

Al-Baihaqy. Abu Bakr Ahmad b Husain (1344H) Sunan al-Kubra. Heidar Abad: Majlis Dairat al-Ma'arif al-Nazamiyyah.

Al-Humaidy. Muhammad b Futuh (2002) al-Jam' Bayn al-Sahihayn al-Bukhary Wa Muslim. Beirut: Dar al-Nasyr.

Al-Baihaqy. Abu Bakr Ahmad b Husain (1410H) Syu'ab al-Iman. Beirut: Dar al-Kutub al-Imiyyah.

Al-Naysabury. Abu al-Husayn Muslimb al-Hajjah. ( t.t) al-Jami' al-Sahih al-Musamma Sahih Muslim. Beirut: Dar al-Jil.

Badlihisham Mohd Nasir. (2010). Pendidikan Islam dalam gerakan Islam di Malaysia: satu tinjauan. Journal of Islamic and Arabic Education. 2(1), 1-12.

Elliott, R. \& Crosswell, L. (2001)./ Commitment to Teaching: Australian Perspectives on the interplay of the professional and the personal in teachers' lives. Paper presented at the International Symposium on Teacher Commitment conducted at the annual conference of the European Educational Research association, Lille, France.

Fathiyah Mohd Fakhruddin, Asmawati Suhid, Lukman Abd Mutalib dan Samsilah Roslan. (2012). Perkembangan sekolah Islam swasta dan sumbangannya kepada sistem pendidikan negara. Paper presentation at the $3^{\text {rd }}$ International Conference on Islamic Education 2013 (ICIED 2013) on 6-7 April 2013 at Pusat Latihan Esset KWSP, Kajang, Selangor.

Huberman, M. (1993). The lives of teachers. London: Cassell Villial House.

Khalid Muhammad Muharram (2006) Bina' al-Syahsiyyah Min Khilal al-Tarbiyyah al-Islamiyyah. Beirut: Dar al-Kutub al-Ilmiyyah.

Nias, J. (1989) Primary teachers talking: A study of teaching as work. London: Routledge.

Rosnani Hashim. (2007). Liberalisasi pendidikan dan cabarannya dalam kontek pendidikan Islam di Malaysia. Jurnal Pendidikan Islam. 12(2), $19-40$.

Said Ismail Ali (2007) Usul al-Tarbiyyah Islamiyyah. Amman: Dar al-Masirah (2006) Halal Haram. Penang. Penang Consumer Association.

Tsui, K. T. \& Cheng, Y. C. (1999). School organizational health and teacher commitment: A contingency study with multi-level analysis. Educational Research and Evaluation, 5(3), 249-268.

Tyree, A.K. (1996). Conceptualizing and measuring commitment to high school teaching. Journal of educational research, 89(5), 295304.

Watson, A \& Hutton, N. (2002). Teachers in mid-career: Professional perceptions and preferences. Report for the New South Wales Teacher's Federation and the Federation of Parents and Citizen's Association of New South Wales, Australia. 